\title{
A Content Analysis of An ISIS‘ Article of Hatred
}

\author{
Achmad Fanani \\ \{achmadfanani@fbs.unipdu.ac.id\} \\ Universitas Pesantren Tinggi Darul Ulum, Komplek Ponpes Darul Ulum Peterongan Jombang, East
} Java, Indonesia

\begin{abstract}
This current research is to expose the grammar of mood in a Rumiyah's article entitled 'The Kafir's wealth is halal for you, so take it'. A content analysis is implemented. This research is done qualitatively. The results of the research indicate that the author mostly uses the declarative mood that function as a statement of opinion, a statement of fact, and an indirect directive. The mood types that are utilized indicate five strategies of persuasion namely (1) 'Nature of situation' to express his opinions; (2) 'Authority appeal' to express that the arguments are from an influential sources; (3) 'Duty' to indicate that taking the wealth of a kafir (non-Muslims) is an Muslim's obligation to fulfill; (4) 'Logical empirical' to clarify the statements from Allah or the Prophet; and (5) 'Assertion' to deliver strongly the obligation to do something.
\end{abstract}

Key words: ISIS, persuasion, hatred, wealth, non-Muslim

\section{Introduction}

Al Hayat Media Center which is a media wing of ISIS has been making many online propaganda magazines. Rumiyah is one of the prominent ISIS' online magazine written in various languages including English. The magazine is to target the readers outside middle east countries. Rumiyah is used as one of the media to recruit foreign sympathizers from many countries and nationalities [23]. According to European Union, ISIS one of the most succesful jihadist group to recruit young people from Western countries compared with other jihadist groups such as Al-Qaeda, [2].

One of the prominent narrative in ISIS propaganda is hatred toward non-Muslims (mushrikin). But how does ISIS use language in their propaganda in order to arouse the hatred of the Muslims toward non-Muslims? An influential linguistic strategies must be applied by ISIS to have the readers act in accordance with them. According Wardhaugh [4] aan alteration of topic of discussion needs an alteration in the language that is used. It implies that different topics of persuasion needs different linguistic techniques or strategies to apply. For example, convincing someone to dislike another one will probably require linguistic strategies that are different from convincing the same person to perform everyday tasks as a Muslim.

This present paper was to disclose the grammar of mood of the clauses employed by ISIS to persuade their readers to hate mushrikins (non-Muslims) as the foes of Islam. An article entitled 'The Kafir's wealth is halal for you, so take it' that exists in Rumiyah the $8^{\text {th }}$ edition was selected for analysis because it is a very provoking article persuading the readers not to be hesitant in taking the wealth of their enemies. The author convinced the readers that the wealth of mushrikin can be taken as ghanimah. Through this article, ISIS followers throughout the world were called out to take any mushrikin's wealth. This is because the mushrikins are real enemies for the Muslims (p. 13). Rumiyah gives the readers many examples of hadith and the 
Qur'an where the wealth of the mushrikin who lost on the battlefield can be taken as ghanimah (spoils of war). In this article Rumiyah also explains the principles of the distribution of ghanimah (p. 14).

\section{ISIS Language of Propaganda}

ISIS' language has been the focus of study around the world such as those done by Vergani \& Bliuc [1], Georges [5], and Fanani et al. [23]. Unfortunately, mostly they were concerned with the word level instead of grammar. They talked about certain words that become so influential in ISIS language. However, one cannot just rely on power words to persuade others. One should be able to compose the words in a powerful clause or sentence to make them more influential in persuasion. To be powerful in ordering, directing, guiding, or convincing others right choices of grammar should be concerned with.

\section{Mood System}

In the Hallidayan interpersonal meaning, mood system is strongly connected with the language of persuasion, because a clause's mood indicates the author's view of the state of being [6]. For example, the imperative mood is likely to indicate the author's / speaker's wishes something to happen. In the interpersonal meaning, the use of language to relate with each other and their use to convey views and attitudes is analyzed at the clause level [6]. The clause can be to inform or question, order or offer, and judge something and express attitudes towards whoever we are talking about [7].

Indicative and imperative are the basic terms in the mood system 6];[22]. The indicative clause deals with an information exchange (negotiation of a proposal), while the imperative clause deals with the application of an action to give services or exchange goods.

In the indicative mood, two terms exists, namely declarative and interrogative. A declarative has a typical speech function of statement (facts, opinion, etc.), giving information. The interrogative is typically to function as a request of information [6]. The imperative Mood is typically used to order, request, and direct someone or something [8] [9]. However, a mood type is not always corresponds to its typical speech functions. For instance, a declarative may function as a directive as in 'You should sit here'.

Some researchers (e.g., [10];[11]) has done an analysis from a mood point of view on the language of political propaganda. The analyzes, though, usually apply only to the exposing of mood styles and the explanations for their persuasive application. Ayoola [10], for instance, has worked out a analysis of chosen advertisements of two political groups in the last national election in Nigeria. Eight separate adverts were analyzed to see how language was utilized by the Nigerian political leaders to communicate their viewpoints through advertising. Ayoola discovered that the interpersonal sense of a system was not really one on one with its lexicogrammar interpretation. This is because the political advertisers liked using various styles of mood to connect, compromise, build and maintain positive relationships with the readers and change their behaviour. He found that the disparity of mood styles in both political parties' adverts as well as their interpersonal meanings was influenced by contextual factors such as the need to reflect the nation's conditions of economy and socio-political situation. He did not, however, describe how the components of the mood influenced the persuasiveness of the advert text. 


\section{Method}

This present research uses a discourse analysis. This research was done qualitatively to identify how certain patterns of mood were utilized to persuade the readers to hate mushrikins. The data (clauses) were taken from an article entitled 'The Kafir's Wealth Is Halal for You, So take It'. The article was issued in Rumiyah magazine the $8^{\text {st }}$ edition. The article was then broken down into clauses which eventually became the data of this research. The article was made up by 48 major clauses, which became the data to analyze.

To get the data, a simple sentence or a complex sentence was regarded as one clause because it is composed by one major clause only. Whereas a compound sentence was treated differently. A compound sentence which consists of three manjor clauses, for example, is counted as 3 clauses. The collected major clauses (the data) were then examined by applying Spradley's cultural theme analysis which includes domain, taxonomy, componential, and cultural theme analyses. The discussion (the cultural theme) was to see how the mood reflected the strategy of persuasion for specific purposes.

\section{Results}

The following table shows the domain, taxonomy, and componential analysis of the clauses in the text.

\section{Domain analysis of the mood in the text}

In the text there are 48 major clauses in. All of the clauses are group in accordance with their speech functions.

Table 1: The domain analysis of the clauses in the Text

\begin{tabular}{|c|c|}
\hline Domain & Number of clause \\
\hline Statement of fact & $44 \%$ \\
\hline Statement of opinion & $42 \%$ \\
\hline Indirect directive & $13 \%$ \\
\hline Optative & $2 \%$ \\
\hline
\end{tabular}

Table 1 shows the domain analysis of the mood in the Text. In general, the clauses in can be grouped into four domains. They are statement of fact, statement of opinion, indirect directive, and optative.

In the text the statements of fact and the statement of opinion are the dominant domains. As many as $42 \%$ of the clauses in the text are categorized as statements of opinion 
while $44 \%$ of the clauses belong to the statement of fact. In the text one more domain exists that is optative which consists only one clause.

\section{Taxonomy Analysis of the Mood}

Table 2 shows that all clauses in each domain are delivered in the declarative mood, as indicated by the $\mathrm{S}+\mathrm{F}$ construction of the clause as in "Ash-Shafi'i said, "..." (Clause 12)". In this clause, 'Ash-Shafi' $i$ ' is the Subject $(\mathrm{S})$ and 'said' is the Finite+Predicator $(\mathrm{F}+\mathrm{P})$.

Table 2: Taxonomy Analysis of the Mood

\begin{tabular}{|c|c|c|c|}
\hline \multirow{2}{*}{ Domain } & \multicolumn{3}{|c|}{ Mood Type } \\
\cline { 2 - 4 } & Declarative & Interrogative & Imperative \\
\hline $\begin{array}{c}\text { Statement of } \\
\text { opinion }\end{array}$ & $20(100 \%)$ & - & - \\
\hline Statement of fact & $21(100 \%)$ & - & - \\
\hline Indirect directive & $6(100 \%)$ & - & - \\
\hline
\end{tabular}

There is one thing in common regarding the mood type composition in the clauses. The text is composed by a declarative mood either in the domains of statement of opinion, statement of fact, and indirect directive, and optative. In the domain of opinion, 20 clauses $(100 \%)$ are written in the declarative mood. In the domain of statement of fact, 21 clauses $(100 \%)$ are written in the declarative mood. In the domain of indirect directive, 6 clauses $(100 \%)$ are delivered in the declarative mood.

\section{Componential analysis of mood}

As shown in table 3 it can be seen that as in the previous texts in Narrative 1 and Narrative 2, there are differences of presentation of the clauses in the same domain in the same type of mood. Generally speaking, in Text 1 there is a contrast of presentation among the declarative clauses in the domain of indirect directive and statement of opinion. It is identified that $63 \%$ of the declarative clauses in the domain of indirect directive are presented by using the technique of presenting the obligation to do something (PODS), the other $25 \%$ of the declarative clauses are presented by employing the technique of presenting prohibition of doing something (PPDS), and the rest $12 \%$ of the declarative clauses are delivered by using the technique of giving suggestion.

Table 3: Componential Analysis of the Mood

\begin{tabular}{|l|c|c|c|}
\hline \multicolumn{1}{|c|}{ Domain } & Mood type & Technique of presentation & $\%$ \\
\hline Indirect directive & Declarative & $\begin{array}{c}\text { presenting the obligation to do } \\
\text { something }\end{array}$ & 63 \\
\hline Indirect directive & Declarative & $\begin{array}{c}\text { Presenting prohibition of doing } \\
\text { something }\end{array}$ & 25 \\
\hline Indirect directive & Declarative & Giving suggestion & 12 \\
\hline $\begin{array}{l}\text { Statement of } \\
\text { opinion }\end{array}$ & Declarative & $\begin{array}{c}\text { giving an evaluative opinion of } \\
\text { something }\end{array}$ & 84 \\
\hline
\end{tabular}




\begin{tabular}{|l|c|c|c|}
\hline $\begin{array}{l}\text { Statement of } \\
\text { opinion }\end{array}$ & Declarative & $\begin{array}{c}\text { presenting the characteristic of } \\
\text { something }\end{array}$ & 16 \\
\hline Statement of fact & Declarative & Telling someone saying something & 100 \\
\hline
\end{tabular}

In the text, in the domain of statement of opinion, $84 \%$ of the declarative clauses are presented by using the technique of giving an evaluative opinion of something (GEOS), while the other $16 \%$ of the declarative clauses employ the technique of presenting the characteristic of something (PCS). However, in the text, all the declarative clauses (100\%) in the statement of fact domain are written by using the technique of telling someone saying something.

\section{Discussion}

The results show that the declarative mood dominates the text which is separated into three domains. They are the domain of statement of opinion, the domain of statement of fact and the domain of indirect directives. Those different domians have particular roles in the persuasion of hatred.

The abundant use of the declarative mood indicates that the author would like to put himself as an informaton provider rather than a commander. The author avoid using pronouns such as 'I' or 'we' (inclusive) to make the information sounds more objective. The declarative mood helps the author reduce his gap with the readers so that the information can be received by the readers straightly. This is definitely unlike the interrogative or imperative mood that need responses from the readers or audiences to know the effectiveness of a proposition[6].

Many of the clauses gives some opinions and facts in this text. The author commonly provides his evaluative opinion to arouse hatred towards the kuffar. The clauses of facts usually quote the statements from Allah, the Messenger, or Muslim scholars. Some of the clauses in the texts also explixitly present the duties of a Muslim, which is an indirect order to do something. Again, the author acts as an advisor or an information bearer of the messages of Allah or the Prophet instead of as the commander.

Though the declarative mood is dominantly found in the text, the mood does not essentially serve as a statement. This is as what Ayoola revealed in his study[10] which told that the mood type does not always correspond to its lexicogrammar. For example, a certain declarative mood in this text, instead of functions as statement, functions as an indirect command by which the speaker gives an order to do something. Clause 45 , for example, tells the readers about the duty of a Muslim as represented by the modal 'must'. This clause is certainly an order to the readers to hate and hurt the kuffar in their own territories.

This text is aso characterized by indirectness which is influenced by some factors. The first factor is the author's relationship with the readers which is relatively separated, because they do not know each other. Theoretically, the less intimacy with the readers will make the author resort to indirectness[14]. This is to avoid what is known as Face Threatening Actions (FTA)[15]. Nesides, the level of the risk is onother factor that may influence the choice of indirectness. The greater the risk, the more indirect the language utilized[16]. In this text, the risk of taking the property of the kuffar is very high. Therefore, the author resorts to use indirectness in the form of a recommendation to the readers. The author commonly utilizes the word 'permissible' or 'halal' to make a suggestion. 
In the text, the statement of opinion is also commonly found which is commonly utilized to arouse the readers' emotions. For this aim, the author uses some emotional words put in the elements of subject, predicator, complement, or adjunct. This is as what Vergani \& Bliuc revealed in their study[1]. They found out that ISIS' language increasingly uses emotions for mobilization. In this text, the author tries to arouse the readers' negative emotions to the kuffar by using many words that negatively characterize them, hence give permissibility of harming them.

This opinion-making (giving a negative opinion to the non-Muslims) indicates the application of the 'nature of situation' strategy of persuasion[17]. It is due to the fact that the author puts himself as the person who has a good knowledge about the matter of discussion, hence the nature of something. By acting as an expert, the author makes definitions or gives meaning to something, or even interprets the statements of Allah and the Prophet. As an expert, his definitions or evaluations on something will look convincing or accurate since they are grounded on strong facts[18].

The declarative mood whose function is as a statement of fact is used by quoting the statements from Allah, the prophet, or Muslim figures. This is as revealed by Georges in his research [5] that ISIS “ propaganda frequently utilizes the words from Allah and the prophet. By citing the words from Allah and the prophet, the author in fact uses the strategy of persuasion of 'authority appeal'[17].

This strategy of persuasion is very operational because people incline to do what authorities ask them to do. People tend to believe whatever they say. The principle of authority is an instance of the human incination to use judgment heuristics. It means that people in the authority position may possess better understanding and power. This further implies that doing what they ask to do will surely result in a positive outcome [19]. In this text, the application of this strategy implies that the author want to tell the readers that taking the wealth of the mushrikin is an order from a strong authority (i.e., Allah and His messenger). Therefore, observing it will be a sign of iman (strong belief). Mulholland[20] said that powerful authorities would help a persuader do his/her job by minimizing any disagreement. To be powerful, the authority must be the one who are well respected by the audience/readers. For example, one may cite Allah or Prophet Muhammad to Muslims, or Chomsky to linguists.

This strategy also shows the application of another persuasion strategy, that is 'duty'[17]. The author, in this case, would like to explain that taking the wealth of the a kafir is a honorable duty that must be observed earnestly. Duty is mainly related to law or regulation. Straker[21] explained that much of our lives are guided by law, rules or regulations, from the national law and regulations to religious law, company policies, social norms, personal values, and family ways. Adhering to any of these rules or regulations is a duty to fulfill. In other words, we can say that disobeying the rule, will certainly cause bad consequences.

Citing a Muslim scholar's statements is aimed at explaining the words of Allah or the Prophet. Thus, this is an implementation of the Kellerman's and Cole's startegy of 'logical empirical'[17]. The power of an argumentation may be increased by using a direct citation from a powerful authority[18]. Within this strategy, the author quotes an explanation from Muslim scholars to give a powerful basis to the propositions presented. In this case, the Muslim scholars whose statements are commonly quoted are the prominent figures in Islam whose opinions and explanations are commonly obyed and observed.

In the declarative mood functioning as an indirect directive, the obligations doing something are strongly offered to the readers. In persuasion strategy, it is involved in the 'assertion' strategy[17] where the author compellingly states an obligation of doing something. 
An assertion is a stylistic approach including a strong statement, a powerful, and positive statement regarding a belief or a fact. An assertion is frequently a covered appeal to authority in that it makes the assumption that the person making the assertion is an expert or has a position of indisputable formal authority [21]. Assertion with the directive function will make the readers act more quickly and observe more faithfully, specifically when the order comes from a very powerful source (e.g., Allah, the Prophet).

In sum, from the types of mood and their speech-function realizations, it can be inferred that the author put himself in the position of information giver and usually uses declarative clauses to function as an indirect directive, a statement of fact, and a statement of opinion. Commonly, the author in this text give a suggestion to the readers to do something in certain ways.

Overall, the results indicates that ISIS does not only rely on the power words like khilafah, Allah, etc. to persuade their potential recruits as proposed by Georges[5] but also on the grammar of the mood. The author skillfully uses grammar in persuading the readers. For example, in persuading them to do something, the author resorts to a softer grammar (i.e., declarative clause) rather than to the blatant grammar (i.e., imperative mood). It means that the author has understood that a particular form of grammar will have particular consequences on the readers, which may make them agree or disagree with him.

\section{Conclusion}

The results as well as the discussion indicate that the author mainly utilezes softer clauses in persuading the readers. He positions himself as an information giver as indicated by the abundant use of declarative mood in the text. With this type of mood, the author can shorten the distance between him and the readers. Therefore the information can be instantly received by the readers. The declarative moodis commonly used by the author to present opinions, facts, and indirect instructions. Emotive words characterize the author's opinions in this text, which is to arouse the readers' negative emotions to non-Muslims. The facts are mostly presented by directly quoting the statements from powerful sources. The author uses the indirect directives by using the declarative mood that shows obligation and prohibition.

The author uses five strategies in this text, namely 'nature of situation' strategy to deliver his opinions; the 'authority appeal' strategy to indicate that they are an order from very influential sources; the 'duty' strategy to say that taking the wealth of mushrikin is a noble obligation of a Muslim; the 'logical empirical' strategy to clarify and explain the statements from Allah or the Prophet; and the 'assertion' strategy to state convincingly an obligation or a prohibition of doing something. In this text, the statement of fact (direct quotation) becomes the key element in persuading the readers.

\section{References}

[1] Vergani, M., \& Bliuc, A.-M. The evolution of the ISIS' language: a quantitative analysis of the language of the first year of Dabiq magazine. Sicurezza. 2015. 7-20. 
[2] Archick, K., Belkin, P., Blanchard, C. M., Humud, C. E., \& Mix, D. E. European Fighters in Syria and Iraq: Assessments, Responses, and Issues for the United States. Washington, D.C:. Congressional Research Service. 2015.

[3]Azman, N. A. Islamic State (IS) Propaganda: Dabiq and Future Directions of 'Islamic State'., RSiS. 2016. Vol. 8, 3-8.

[4] Wardhaugh, R. An Introduction to Sociolinguistics. Oxford: Blackwell Publishing. (2006)

[5] Georges, A. ISIS Rhetoric for the Creation of the Ummah. Abu Dhabi: TRENDS Research \& Advisory. 2015.

[6] Halliday, M., \& Matthiessen, C. M. An Introduction to Functional Grammar. New York: Oxford University Press Inc. 2004.

[7] Eggins, S. Introduction to Systemic Functional Linguistics. New York: Continuum. 2004.

[8] Lyons, J. Semantics. Cambridge: Cambridge University Press. 1977.

[9] Palmer, F. R. Modality and the English Modals. London: Longman. 1979.

[10] Ayoola, M. O. An Interpersonal Metafunction Analysis of Some Selected Political Advertisements in Some Nigerian Newspapers. IJHSS, 2013.165-178.

[11] Gass, R. H., \& Seiter, J. S. Persuasion, social influence, and compliance gaining (4th ed.). Boston: Allyn \& Bacon. 2010.

[12] Simons, H. W., Morreale, J., \& Gronbeck, B. Persuasion in Society. Thousand Oaks London New Delhi: Sage Publications, Inc. 2001.

[13] Dillard, J. P., \& Pfau, M. The Persuasion Handbook: Developments in Theory and Practice. Thousand Oaks, CA: Sage Publications. 2002.

[14] Khalib, F., \& Tayeh, A. Indirectness in English Requests among Malay University Students. Procedia. 2014. 44-52.

[15] Brown, P., \& Levinson, S. C. Politeness: Some Universals in Laguage Usage. Cambridge: CUP. 1987.

[16] Leech, G. N. Principles of Pragmatics . London: Longman. 1983.

[17] Kellermann, K., \& Cole, T. Classifying compliance gaining messages: Taxonomic disorder and strategic confusion . Communication Theory. 1994. 3-60.

[18] Clark, J., Wegener, D., Habashi, M., \& Evans, A. Source Expertise and Persuasion: The Effects of Perceived Opposition or Support on Message Scrutiny. Personality \& Social Psychology Bulletin. 2011. 38(1): 90-100. 
[19] Fessenden, T. (2018, February 4). https://www.nngroup.com/articles/authority-principle/. Retrieved January 4, 2020, from www.nngroup.com:

https://www.nngroup.com/articles/authority-principle/

[20] Mulholland, J. Handbook of persuasive tactics, A practical language guide. London and New York: Routledge. 1994.

[21] Straker, D. (2002, January 2). http://changingminds.org/techniques/. Retrieved January 4, 2020, from http://changingminds.org/:

http://changingminds.org/techniques/general/kellerman/duty.htm

[22] Fanani et al., (2020). Donald Trump's grammar of persuasion in his speech, Heliyon, 6(1):1-7 https://doi.org/10.1016/j.heliyon.2019.e03082

[23] Fanani et al., (2020). ISIS' grammar of persuasion of hatred in the article 'The Kafir's blood is halal for you, so shed it' published in the Rumiyah magazine, Heliyon, 6(7):17 doi: $\underline{10.1016 / \text { j.heliyon.2020.e04448 }}$ 